https://doi.org/10.18485/iipe_ru_sr.2020.ch15

\title{
AMERICAN GEOPOLITICS IN CONTEMPORARY EURASIA: WHAT MUST BE DONE AND CAN GLOBAL LEADERSHIP BE PRESERVED?
}

\begin{abstract}
Dušan Proroković ${ }^{1}$
Abstract: The research question that is being answered is: Can the United States retain its position as a global leader? Or: What does the United States need to do to get back to its position before 2008? The theoretical framework in which the answer is sought is classical geopolitics. More specifically, the dualistic concept of the constant clash of the Tellurocratic and Thalassocratic forces, the Continental and the Maritime powers. Therefore, the scenarios that predict what the United States has to do are directly derived from geopolitical logic. The specific methods used in this research are analysis, synthesis, abstraction, induction, and deduction. The research aims to examine the potential activities the United States can take to maintain global leadership. In this context, the research objective is related to scientific description and prediction.
\end{abstract}

Keywords: American geopolitics, Thalassocracy, global leadership, China, Russia, Japan, Europe, Islam.

\section{Introduction}

Make America Great Again! It was a slogan in 2016 Donald Trump's presidential campaign. And after that, Trump continued to use it. Actually,

\footnotetext{
${ }^{1}$ Research Fellow, Institute of International Politics and Economics, Belgrade, e-mail: dusan@diplomacy.bg.ac.rs.

The paper presents findings of a study developed as a part of the research project "Serbia and challenges in international relations in 2020", financed by the Ministry of Education, Science, and Technological Development of the Republic of Serbia, and conducted by Institute of International Politics and Economics, Belgrade.
} 
this slogan is just a derivative of Ronald Reagan's 1980 election campaign: Let's make America great again. Even then, in the early eighties, the United States was facing big challenges. Reagan succeeded. (Hayward, 2009, pp. 403-558) America has become great again. The greatest! Victory in the Cold War left the Unites States (the US) as the only superpower in world politics. The new world order was unipolar. Can Trump make America great again? Can America return to the positions it held before 2008? In 2011, "the Pentagon's new strategic guidance" was named: Sustaining U.S. Global Leadership: Priorities for the 21st Century Defense. (Hammes, 2012, p. 1)

This paper presents one scenario: what America needs to do "to become great again". Namely, what to do to return to previous positions. The theoretical framework is classical geopolitics. More specifically, the dualistic concept of the constant clash of the Tellurocratic and Thalassocratic forces, the Continental and the Maritime powers. (Proroković, 2018a, pp. 31-44) Of course, the United States is the largest thalassocratic force, maritime power seen in world history so far. The fact that Trump returned to Reagan's slogan shows us that the US position is in jeopardy. Or more precisely, that US global leadership is being jeopardized.

\section{Geopolitical problems and security threats for the United States}

The question is: Can America keep global leadership? American global domination is over, and leadership is seriously endangered. (Zakaria, 2008, pp. 49-128; Ferguson, Zakaria, 2017) Numerous factors show that we are witnessing the creation of the multi-polar world. In this new multi-polar structure, the United States could be the most powerful military and one of the most powerful economic poles in the world. (Proroković, 2018b) But current trends in international politics suggest that this may not be enough for the United States to sustain a possible "new global leadership".

New (macro) regional geopolitical players appear in different parts of the world, who, in order to realize their interests, are ready to push out the American interests. Of course, the US is more or less present in all parts of the world and capable to defend its interests "to some extent". Compared to the current situation and especially to the US position in international 
relations during Bill Clinton's second term and the first term of George W. Bush, it would mean significant erosion.

There are three major "internal problems" that the United States is facing in international politics. The first one is an unstoppable process of the decline of American economic power on a global scale. (Lachmann, 2011, pp. 44-49) While in the period immediately after World War II, the US economy accounted for almost half of the global economy, today's this comes down to a quarter. The current economic crisis only further undermines the US position. The second problem is the fact that the image of the United States in the world has changed in the last two decades. The seductiveness of "the American values" is gone. According to Zbigniew Brzezinski, globalization has also made the global awakening that is distinctly anti-American. (Brzezinski, 2012) After the scandal with Wikileaks and information discovered by Edward Snowden, American talks about the struggle for democracy, reforms, and human rights have lost credibility. This makes it harder for the US to rely on "soft power". The third problem is the decline of military domination. American rivals are increasing their military expenses, and they are constantly developing new weapons. However, it is important to underline that the weakening of the US in this area is the least evident since the United States continues to spend on defense as all other countries in the world together. Despite all, the military force remains an instrument on which the US can rely on in realizing its foreign political goals.

In order to keep global domination, the United States needs to work on achieving economic consolidation, keeping technological supremacy, and modernization of the existing (development of new) kind of weapons. This requires a change in current trends. And this change is impossible without stopping rivals in different parts of the world. Increasing aggressiveness in foreign politics and daring performances of new (macro) regional powers present an "external problem" for the US. Therefore, the battle that the US will lead in the next decades will primarily be geopolitical!!

What are the most important "foreign problems" for the United States: 1) China's continuous economic growth (economic empowerment has caused and increased allocations for military purposes) and its geoeconomic positioning in East Africa, Southeast Asia, the eastern part of Central Asia, and partly in the Middle East and Western Eurasia (Eastern Europe); 2) institutional and economic consolidation and military 
strengthening of Russia (including the modernization of all types of weapons and equipment); 3 ) desire of long-standing partners, the leading West European countries and Japan, to play a more independent role and on certain issues even to go against the American interests; 4) struggle for leadership in the (so-called) Muslim world; 5) reduction of regional powers technological delay in comparison to the US; 6) strengthening of antiAmericanism in different parts of the world, especially between Muslims.

\section{How to keep global leadership: Priorities in American geopolitics}

Therefore, the following priorities are imposed on the United States: containment of China; exhaustion of Russia; controlling of the EU and Japan; directing Islam. Successful resolution of these "external problems" would be a "half-way" to solving the "internal problems". These priorities are interconnected in a great deal. Exhaustion of Russia could open room for directing China towards the Russian Far East territories and for the redirection of the West European NATO members towards the Russian sphere of interests in the east part of Eurasia. The weakening of the Russian position is, on the one hand, suitable for the US, but on the other hand, it would also strengthen the position of China and the EU, which is not in the American interest. China's rapid decline would arouse geopolitical expansionism in Japan, and due to that Japan would eventually become a US rival in the Pacific. The direction of Islam could produce a great intercivilizational conflict that could contribute to the containment of China, exhaustion of Russia and control of the EU, but it could also turn out into a large intra-civilizational conflict that will, even more, complicate the situation in the Middle East. This is why it is hard to define what should be the order of the realization of these priorities. Maybe some of them could be realized simultaneously, but they should certainly be well-coordinated for a long period. How could the aforementioned priorities be realized?

\section{Containment of China}

The containment of China would mean bringing down its current (three decades old) economic growth and successful control of future economic trends. US military resources in the Pacific seem to be insufficient for the 
containment of China's geo-economic influence, and reliance on the coastalinsular "geostrategic arc" South Korea-Japan-Taiwan-Philippines could have only a limited effect. (Hammes, 2012, pp. 3-7) These resources can help to stop China's exit to the World Sea, but this does not mean the desired containment. The containment of China will only be successful if the following three measures are realized: 1) creation of an effective continental geostrategic arc at the southwestern border of China. In this context, it would be significant for the US to encourage the India-China rivalry, but also to work on bringing Myanmar and Vietnam to its sphere of interests; 2) prevention of China's strategic linkage with Russia; 3) disabling further strengthening of China-Pakistan relations. Immediate steps to achieve these three measures would probably be the following: 1) obstruction of the BRICS work in order not to allow the improvement of Sino-Indian relations and the Sino-Russian strategic connection through this multilateral configuration; 2) constant disruption of Sino-Russian cooperation always and on every place, creating a public opinion that the Sino-Russian conflict is inevitable in the future (China needs resources and the Russian Far East territories are sparsely populated!?); 3) working on attaining a more significant influence on Kazakhstan. Kazakhstan is one of two Russia's strategic partners in the post-Soviet space (next to Belarus). This fact alone is a reason enough for the US to have the interest to influence political processes in this country. But Kazakhstan could also be used as a tool for long-term disturbance of Sino-Russian relations. In this regard, the United States could encourage China to seek its link with continental Europe through the old "Silk Road" which leads through Kazakhstan (one route of the Belt and Road Initiative); 4) ensuring adequate investments that could significantly improve the economic and social situation in Myanmar and Vietnam (thanks to low production costs, they are currently more attractive than China, so there is also an economic justification for this step!), then signing an agreement on military cooperation with these two countries; 5) putting a constant pressure on ASEAN to ensure anti-Chinese posture; 6) establishing a notable presence in Malaysia and Indonesia to ensure limited and directed strengthening of the radical Islamist groups in these countries. South Asian radical Islam can be directed against the Chinese interests in this region, and to this end opening of the "Uyghur issue" can be used, as well as maintenance of latent conflict in Xinjiang (Xinjiang's Palestinization). With this approach, all 
Muslim nations in this part of the world (or the majority of Muslim countries in the world) could turn to the extreme anti-China position; 7) the gradual opening of a conflict between South Asian Muslims and China and the Palestinization of Xinjiang would create a favorable environment for long-term disturbance of Sino-Pakistani relations. Thus, China would be completely directed towards Kazakhstan as the only western neighbor on which one can significantly rely, adversely affecting its relations with Russia; 8) continuation of more significant military cooperation with India and helping India to expand its influence as far as possible to the east (to the border with China). At the same time, Chine would be trying to calm Indian-Pakistani hostilities and create an acceptable framework for cooperation between the two countries.

\section{Exhaustion of Russia}

In the last decade and a half under Vladimir Putin, Russia has undergone an extraordinary journey from the country on the verge of collapse to the pivot of Eurasian integration. The Eurasian Union, which has the ambition to grow from an economic into a political integration and expand territorially, is cause for concerns in the United States. The Eurasian Union has the capacity to become one of the most significant regional integrations in the world. (Golam, Monowar, 2018, pp. 163-172) However, it is visible that the Russian economy is facing a number of structural problems and that it is over-reliant on revenues from the sale of energy. (Eder et al., 2017, pp. 2-4) By creating a Eurasian Union, Russia is trying to change this and accelerate its own economic development, to modernize its technology, and to develop innovative capacity. At the same time, because of Russia's nuclear and other military capabilities (which are rapidly developing), the US must be cautious in its approach towards Russia. Notably, the US is trying to use the media campaign as well as some Russian NGOs and political organizations to destabilize the internal political structure (power pyramid) in Russia. The effects of these efforts are small due to the decreasing influence of instruments of soft power in the political process. The internal destabilization of Russia is possible only through the dramatic disruption of existing social relations, and this can be done only through the deterioration of the economic situation. This can be achieved in two ways: 1) by direct impact on Russian budget revenue (revenue from the sale of energy) that can be realized if the US gets under its direct control sources 
of natural gas in Central Asia (notably this applies to sources in Iran, the second-biggest reserves of natural gas in the world). This would help reduce the dependence of some consumers from Russian gas. This can also be done by preventing the construction of new pipelines from Russia to end-users, primarily towards the EU; 2) directing Russia towards a different allocation of budgetary resources. This can be accomplished by opening a number of security issues that would lead Russia into a new "armament race" forcing it to assign a greater amount of resources to the military budget. In addition to these measures, the Muslim factor (about 8.5-10\% of the total population of Russia, concentrated on the sensitive geostrategic points) and directed campaigns to strengthen nationalism can be used for the internal destabilization of Russia.

On the one hand, the strengthening of Russian nationalism would produce a growing intolerance toward non-Russian nations, thereby causing conflicts (about $17.5 \%$ of the Russian population is non-Slavic). On the other hand, the strengthening of nationalism among non-Russian nations would create a tendency towards independence and secession (although separatism, except in isolated cases, is not noticeable, it should be noted that there are 22 republics in the constitutional system of the Russian Federation, including the Republic of Crimea).

This would mean the depletion of Russia. As a result, the country would have growing economic problems, which would cause social tensions and quickly produce ethnic and religious intolerance. Thus, Russia would be thrown from the tracks, and possibly even its existing borders would be questioned. How can this aim be accomplished? The goal could spread out a "geopolitical anaconda" around Russia's body, just as Alfred Mahan suggested a long time ago. (Mahan, 1890) Only now, in order to achieve the effective depletion, the "content" of this geopolitical surrounding would have to be different in different parts of the world.

Looking from the US position, what needs to be done in order to achieve this plan is the following: 1) all Eastern European countries should join NATO. Once Eastern Europe is completely under the "NATO umbrella", it will provide full control of the Russian western border and open up space for endangering its southern border. The problems with NATO expansion have emerged in the post-Yugoslav space (the key American problem in this region is Serbia!) and in the case of Ukraine. Belarus is a similar case, but due to close ties that this country has with Russia (The Union State), NATO 
cannot expect some greater success here (the maximum, in this case, could be the continual undermining of the Russia-Belarus Union through destabilization of Belarus). Regarding the area of the former Yugoslavia, the US has the dominant influence in this region, but it is also facing some problems that could escalate in the future and introduce the Balkans into a new crisis. One of the problems for the US presents the fact that until now the membership in the wealthy EU was used as a means of attracting the Eastern European countries to NATO. Now the EU is in the crisis with no end in sight. Lack of trust in the EU is noticeable in all East European countries. Special attention will be paid to the "Christian-Orthodox" countries in this part of the world, given that they are more or less leaning towards Russia. (Adamsky, 2019) Orthodox countries within the framework of NATO and the EU will have to be directed to have extreme forms of antiRussian activities. In this context, one should observe the installation of the American (anti) missile installations in Bulgaria and Romania; 2) prevent the construction of new pipelines to transport Russian energy through the East European countries to Western Europe. This would reduce the dependence of the European countries on Russian energy, cut the flow of funds into the Russian budget, disable the strengthening of the Russian influence in the transit countries and lessen the risk of creation of the Berlin-Moscow strategic axis; 3) prevent the "return of Russia" to the South Caucasus. The path to the internal destabilization of Russia leads through the Caucasus, and that is why the US needs to keep Georgia and Azerbaijan in its orbit and to try to get Armenia in this group as well. Armenia is the only Caucasian member of the CSTO military alliance, and this threatens the US interests. In order to push out the Russian influence from the Caucasus, the US can use the resources of Turkey. As in the case of the Eastern European countries, the United States could accelerate the admission of Georgia and Azerbaijan in NATO; 4) one of the most effective ways to exhaust Russia is the destabilization of Iran (either by "producing" new revolution or by the military intervention of the US and/or Israel, which would destroy Iranian nuclear installations). The ultimate American target in Iran is taking control over sources of gas and control over the strategically important Strait of Hormuz, but any destabilization of this country weakens Russia's position. Destabilizing Iran would weaken the position of Shias in the region of the Middle East, where Russia was always able to find solid allies. Also, the weakening of Iran would lead to the 
strengthening of Saudi presence in the Central Asian region, which coincides with the US interests. This creates conditions for a more aggressive approach towards the steppe Muslims who so far have demonstrated a high degree of loyalty to Russia (unlike some Caucasian Muslims who in certain historical periods were easily motivated to go into the war against Russia); 5) organize a special program for Kazakhstan, which can be used either as a tool for the outbreak of the Russo-Chinese disagreements or as a "malignant tumor" in the Russian geopolitical stomach. The geographical position of Kazakhstan is such that its transfer to the US track would lead to the collapse of the idea of the Eurasian Union as any kind of integration. (Starr et al., 2014, pp. 16 - 31) To achieve this, the US needs to influence the political and military structures in Kazakhstan; 6) after withdrawal from Afghanistan, to direct Tajiks against Pashtuns. Production of chaos in Afghanistan could lead to the "export of violence" to the north, threatening the Russian interests in Tajikistan; 7) bind Uzbekistan to the US as much as possible, through agreements on military and economic cooperation. Due to a number of open issues in bilateral Kazakh-Uzbek relations, the US reliance on Uzbekistan would threaten the possibility of transferring Kazakhstan to the new tracks. However, due to the participation of Tajikistan and Kyrgyzstan in the Eurasian integrations and their membership in the CSTO military alliance, this is the only possible measure at this time; 8) strengthen the American presence in Mongolia; 9) organize a long and wide anti-Chinese campaign in Russia itself. The Russian public and its political representatives have to be convinced that the main enemy is populous China.

\section{Controlling of the EU and Japan}

After the victory in the Cold War, the efforts of former US allies to become independent geopolitical players are all the more noticeable. The US alliance with the EU countries in the West, which was also manifested through economic cooperation, but primarily through NATO and with Japan in the East, was asymmetrical, with a clear definition of who stands where. The United States was superior, and allies followed its foreign policy priorities. The reason for this was the existence of one common enemy. (Tanaka, 2011, pp. 50 - 56) The collapse of the bipolar world meant the disappearance of the common enemy, and at the same time, the beginning of the growing differences between the US and the European countries and 
Japan. Regarding the European countries, the particular problem for the United States presents frequent disagreements with Germany, although in France one can also often hear that it is necessary to reduce dependence on the US. In the case of Germany, the threat to the US interests is seen in the possibility of the creation of a strategic partnership between Germany and Russia. These two countries are already connected with the strategic pipeline "Nord Stream" and are continuously showing a willingness to deepen bilateral cooperation. While there is NATO, the United States will be in principle able to control the European countries. However, the EU is making significant efforts to form its own military forces, and on the other hand, the European members are showing clear disagreement with certain US moves. (Cooper, 2003) Because of that, the United States could not use NATO military structure for certain interventions. As for Japan, the practice shows that it is unacceptable for the global economic superpower to stay long with modest military capacities. In the bottom line, it would be useful for the US to use everything, including the military capabilities of Japan against the growing influence of China.

A new approach of the United States in the Pacific is unlikely to mean the permanent maintenance of the military weak Japan, but rather allowing the military strengthening of Japan with the obligation of harmonization of geopolitical priorities of two countries. In this context, the measures that the US will take to control more effectively the EU and Japan can be: 1) not allowing the EU to become an independent geopolitical player. Therefore, it is necessary to obstruct all attempts of the EU towards federalization and the creation of common institutions with greater executive and judicial powers; 2) tighter binding of East European and South European members to the United States to maintain a critical mass within the EU that will protect the American interests; 3 ) encourage the rapid expansion of the EU to all Eastern European countries (including Ukraine and Belarus), regardless of the increasing Euro-skepticism and fatigue from the previous expansion. American interest is to keep the EU constantly "politically tired". On the one hand, this would set the "homework" for the EU structures, and it would be at least a decade before they would end this process. At this time any thinking about federalization would have to be postponed. On the other hand, this would open a space for the expansion of NATO to the whole of Europe (except Belarus, but an offer for the EU membership would be given to this country to achieve its internal destabilization and disruption 
of its relations with Russia); 4) latent expansion of anti-German atmosphere in all European countries where this is possible; 5) continuation of strong overall cooperation with Poland and its connection with the three Baltic States (Lithuania, Latvia, Estonia) to prevent the creation of a German-Russian geopolitical corridor; 6) coordination of positions with France in all matters of vital interest to this country (the Maghreb, the Eastern Mediterranean, etc.), and in return, insisting on its participation in the control of Germany; 7) opening the question of the South Kuril Islands and working on gradual "stirring up" of the JapaneseRussian crisis; 8) giving a more important role to Japan in controlling the crisis with North Korea. This measure can be implemented in the coordinated action with South Korea, given that the official Seoul would not look favorably on this arrangement. However, for the US, it is more important that such a measure would further damage Sino-Japanese relations and prevent (already highly unlikely) an alliance between the two powers; 9) promotion of Japan as an important political factor in the Pacific. In this regard, the United States will have to insist that Japan and India become permanent members of the UN Security Council (which would mean a partial change of the previous stand on this question). With this act, the ball would be thrown into the Chinese (and partly Russian) yard, because due to the projected deterioration of Japan-China relations, China would probably be against this proposal.

\section{Directing Islam}

A phenomenon called "the struggle for leadership in the Muslim world" should demonstrate all the problems and differences within the Islamic bloc. Samuel Huntington marked the Muslim world as Islamic civilization. (Huntington, 1997) There are compelling reasons why Huntington did that, but at the same time, it can be said that a single Islamic civilization does not exist (the question is whether it will ever be formed). The differences between the leading Muslim countries are vast, almost insurmountable. These differences are manifested in relation to the dogmatic questions and regarding compliance with the Sharia norms, as well as in relation to the influence of Islam in daily life and the geopolitical setting and the choice of key allies. Because of this, the relationship of the United States with these countries varies. While the Gulf states are strategic allies (especially Saudi Arabia), Iran presents one of the biggest foreign policy challenges, and 
Turkey is on "its way". The other thing is that pan-Islamic radical groups are getting increasingly influential within the Muslim world (their interpretation of Islam has little to do with the original principles of the religion). Although these groups present a threat to the security of the United States at this moment, due to their extremely anti-American and anti-Western stance, they could in the future serve as a useful tool to enhance the US influence in many regions. For the United States, it is important to keep control over the situation in the Middle East and that their allies in the region remain stable. But, at the same time, their interest is to destabilize the biggest rivals in Eurasia, and for that radical Islam can be used. Therefore, on the one hand, it is necessary to strengthen the position of Turkey (as a NATO member) and Saudi Arabia (but in a way in which their strengthening would not jeopardize the interests of Israel) and to fully link Pakistan to the United States. On the other hand, the goal is to attempt the radicalization of Muslim nations in Central and Southeast Asia. Thus, the American strategic allies would be positioned as leading countries in the Muslim world. However, at the same time, "civilization conflicts" would be opened alongside the entire southern rim of Russia border and partially at the southwestern and northwestern border of China. The specific steps that can be taken to achieve these goals are: 1) constant coordination of activities between Turkey and Saudi Arabia, first to limit the influence of Iran, and then to provoke its internal destabilization through armed rebellion. The conflict in Syria should also be seen in this context; 2) not allowing any internal destabilization of Turkey and Saudi Arabia. This would mean allowing Turkey to use all available means to solve the Kurdish issue and letting the ruling Saudi family use all means to prevent tribal rebellions in this country; 3 ) allowing Turkey and the Gulf states to expand their spheres of influence in the areas they are interested in (but so that it does not threaten the US strategic interests): the CaucasusCaspian region, the Balkan peninsula, Crimea, northeastern Africa (including a possible strengthening of the Saudi economic presence in Egypt) and the Maghreb; 4) political and economic isolation, or if possible, destabilization of all potential Russian and Chinese partners in the Muslim world (of particular importance is the continuation of isolation of Palestine, maintaining the current situation in Iraq and further destabilization of Syria; other candidates for this list are already mentioned in the previous sections of the work); 5) channeling the discontent of Islamic nations 
towards the nearest, neighboring civilizations, thereby spreading the impact of radical Islamic groups in the region of Central and South Asia; 6) concentrating on Malaysia and Indonesia as potential allies in containing China; 7) achieving the highest possible degree of influence among the representatives of the Pakistani military, political and economic elite; 8) in this regard and to strengthen the oversight of all operations, it is important to realize the significant military presence in the Indian Ocean (naval forces and maintaining Diego Garcia base) and to keep control over the East African coast (Kenya and Somalia in the internationally recognized borders); 9) supporting the fight against terrorism of radical Islamic groups in the European countries and India.

\section{Conclusion: Global leadership as a historical category}

The described measures and actions that must be taken to preserve global leadership are imposed by simple geopolitical logic. Does America have the strength to make such an approach? A comparison with the Reagan era is somewhat unfounded. At the time, however, the US was in a much better position. Yes, there was the USSR as a challenger, but the US was the "engine of the global economy", the "bastion of democracy" and the "protector of human rights". Being with America, supporting America, copying America, was not only useful but also to some extent prestigious. This showed solidarity with the oppressed, courage in the fight against autocracy. What has left of it today? The room for maneuver for expanding US soft power is so narrow that Donald Trump's position on the world stage is more comparable to that of the Soviet Union in the early 1980s than to Ronald Reagan's. Also, the US is clashing with several challengers at the same time (and these different challengers are different in character and intensity), a phenomenon that they did not encounter after World War II. There are also the classic challengers - Russia (in the contemporary geopolitical context in American eyes Russia is the successor of the powerful Soviet Union) and China, but also yesterday's allies - the Western European states and Japan - with whom relations must be redefined (neither European powers nor Japan cannot agree to a "junior partner" position in relation to the US). In the Cold War bipolar framework, this was simply not 
the case. As a result, the US is forced to rely more on regional allies, which will increase the cost of its geopolitical projects (allies need political support and economic support). Viewed from the "current angle", it is also evident that the United States has a problem with keeping Turkey in the "American" sphere of interest. The signing of energy agreements and agreements on the transfer of military equipment between Russia and Turkey indicates that Ankara is pursuing an independent foreign policy without coordination with NATO. This makes impossible the whole plan to "Directing Islam". Under this plan (described in Chapter 4 of the article), Turkey is a key partner for its implementation.

Basically, the situation that official Washington is facing is quite new. It is incomparable to the Reagan era. The slogan Make America great again may serve to win elections, but at the same time, viewed from the perspective of geopolitics, it is a difficult task in world politics. The US is leading the complex geopolitical fights, which will in the long-run denote its position in international relations, but more importantly, it will denote the structure of the world political system.

To carry out the activities noted and described in order to determine the position of a global leader means to conduct a patient, organized, and coordinated policy. And have hope that the challengers will not recognize these activities as a threat to their own safety. The chances of such a thing are minimal. Therefore, the final statement is that one cannot expect (or in a milder variant that it is difficult to expect in the near future) the return of America to the positions it held before 2008. US global leadership is not only threatened, but it is also most likely a historical category.

\section{Bibliography}

Adamsky, Dmitry. (2019). Russian nuclear orthodoxy: religion, politics, and strategy. Stanford, Stanford University Press.

Brzezinski, Zbigniew. (2012). Strategic Vision: America and the Crisis of Global Power. New York, Basic Books.

Cooper, Robert. (2003). The Breaking of Nations: Order and Chaos in the Twenty-First Century. New York, Atlantic Monthly Press. 
Eder, L. V., I. V. Filimonova, I. V. Provornaya, V. Yu. Nemov. (2017). The current state of the petroleum industry and the problems of the development of the Russian economy. IOP Conf. Series: Earth and Environmental Science, 84 (2017), 012012, pp. 1-5.

Golam, Mostafa, Mahmood Monowar. (2018). Eurasian Economic Union: Evolution, challenges and possible future directions. Journal of Eurasian Studies, Volume 9, Issue 2, pp. 163-172.

Hammes, T. X. (2012). Offshore Control: A Proposed Strategy for an Unlikely Conflict. Strategic Forum, No. 278, Washington D.C., National Defence University - Institute for National Strategic Studies.

Hayward, Steven F. (2009). The Age of Reagan: The Conservative Counterrevolution: 1980-1989. New York, Three rivers press.

Huntington, Samuel P. (1997). The clash of civilizations and the remaking of world order. New York, Touchstone.

Lachmann, Richard. (2011). The Roots of American Decline. Contexts, Volume: 10 , issue: 1 , pp. 44-49.

Mahan, A. T. (1890). The Influence of Sea Power Upon History: 1660-1783. Boston, Little, Brown and Company.

Proroković, Dušan. (2018a). Geopolitika Srbije. Položaj i perspektive na početku XXI veka ( $3^{\text {rd }}$ edition). Beograd, Službeni glasnik.

Proroković, Dušan. (2018b). Era multipolarnosti. Beograd, Službeni glasnik.

Starr, S. Frederick, Bulat Sultanov, S. Enders Wimbush, Fatima Kukeyeva, Svante E. Cornell, Askar Nursha. (2014). Looking Forward:Kazakhstan and the United States. Washington D. C.: Stockholm, John Hopkins University: Institute for Security and Development Policy.

Tanaka, Hitoshi. (2011). US-Japan Relations: Past, Present, and Future. In: New Shimoda Conference: Revitalizing Japan-US Strategic Partnership for a Changing World (pp. 50 - 56). Tokyo, JCIE.

Zakaria, Fareed. (2008). The Post - American World. New York, W.W. Norton \& Company. Ferguson, Niall, Fareed Zakaria. (2017). The end of liberal order? Toronto, Aurea Foundation. 